\title{
PENGARUH SELF MONITORING TERHADAP SELF EFFICACY SISWA DALAM PEMBELAJARAN MATEMATIKA DI SMP KOTA LANGSA
}

\author{
Cut Yanti $^{1}$, Nuraida ${ }^{2}$, Srimulyati $^{3}$ \\ ${ }^{1}$ Alumni Jurusan/Prodi Pendidikan Matematika IAIN Langsa \\ Email: yanti@gmail.com \\ ${ }^{2}$ Dosen Jurusan/Prodi Pendidikan Guru Madrasah Ibtidaiyah IAIN Langsa \\ Email: nuraida72@iainlangsa.ac.id \\ ${ }^{3}$ Dosen Jurusan/Prodi Pendidikan Guru Madrasah Ibtidaiyah IAIN Langsa \\ Email: srimuliati@iainlangsa.ac.id
}

\begin{abstract}
ABSTRAK
Self monitoring merupakan konsep yang berhubungan dengan konsep pengaturan kesan (impression management) atau konsep pengaturan diri. Self-efficacy merupakan keyakinan diri seseorang terhadap kemampuan yang dimilikinya dalam mencapai suatu tujuan berdasarkan hasil yang ditentukan. Kemampuan self-efficacy yang dimaksud dalam penelitian ini adalah keyakinan diri siswa dalam pembelajaran matematika ketika menyelesaikan masalah yang diberikan, menjawab pertanyaan, dan memberikan tanggapan. untuk mengetahui pengaruh Self Monitoring terhadap kemampuan self efficacy siswa di kelas VIII SMP Negeri 6 Langsa. Jenis penelitian ini adalah pendekatan penelitian kuantitatif dengan metode eksperimen. Populasi dalam penelitian ini adalah VIII SMP Negeri 6 Langsa yang sedang aktif belajar pada Tahun Ajaran 2016/2017 yang terdiri dari 6 (enam) kelas yang berjumlah 124 orang siswa. Sampel dalam penelitian ini yaitu kelas kelas VIII.4 dengan jumlah siswa sebanyak 21 orang siswa. Sampel dalam penelitian ini diambil dengan menggunakan teknik simple random sampling. Instrumen yang digunakan berupa tes dan non tes yang berupa angket dan lembar observasi. Data yang terkumpul kemudian dianalisis dengan menggunakan uji t. Berdasarkan hasil analisis data diperoleh bahwa hasil uji hipotesis data post-test kemampuan self efficacy matematika siswa diperoleh $t_{\text {hitung }}=15,60$ dan $t_{\text {tabel }}=2,08$ sehingga $t_{\text {hitung }}>t_{\text {tabel }}$. Dengan demikian dapat disimpulkan bahwa terdapat pengaruh antara Self Monitoring terhadap kemampuan self efficacy siswa di kelas VIII SMP Negeri 6 Langsa.
\end{abstract}

Kata Kunci: Self Monitoring, Self Efficacy

\section{PENDAHULUAN}

Matematika merupakan suatu disiplin ilmu yang diajarkan pada setiap jenjang pendidikan di Indonesia mulai dari Sekolah Dasar sampai dengan perguruan tinggi. Ilmu matematika juga menjadi salah satu bidang studi yang sangat penting dalam kehidupan manusia maupun bagi perkembangan ilmu keilmuan lainnya. Pembelajaran matematika mampu mengembangkan cara berpikir logis , kritis, sistematis dan kreatif. Proses pembelajaran matematika akan lebih baik 
apabila siswa berperan aktif dan siswa ditempatkan sebagai subjek pembelajaran dimana guru sebagai fasilitator dalam aktivitas belajar-mengajar. ${ }^{1}$

Matematika sangat berhubungan erat dengan kehidupan manusia. Kemajuan ilmu pengetahuan dan teknologi yang begitu pesat dewasa ini tidak lepas dari peranan matematika. Boleh dikatakan landasan utama sains dan teknologi adalah matematika. Menurut Masykur dan Fathani bahwa kedudukan matematika dalam ilmu pengetahuan adalah sebagai ilmu dasar, sehingga untuk dapat berkecimpung di dunia sains teknologi atau disiplin ilmu lainnya langkah awal yang harus ditempuh adalah menguasai ilmu dasarnya yaitu matematika. Matematika dapat melatih seseorang untuk berpikir logis, bertanggung jawab, memiliki kepribadian yang baik dan keterampilan untuk menyelesaikan masalah matematika dalam kehidupan sehari-hari. ${ }^{2}$

Menyadari pentingnya matematika, maka belajar matematika seharusnya menjadi kebutuhan dan kegiatan yang menyenangkan. Namun pada kenyataannya masih ada siswa tingkat dasar dan menengah maupun perguruan tinggi yang tidak suka belajar matematika. Hlm ini dapat dilihat dari banyaknya peserta didik yang masih kurang semangat ketika mata pelajaran matematika diajarkan, seperti siswa yang suka berbicara dengan temannya saat guru menerangkan, bahkan siswa sering keluar masuk kelas dengan banyak alasan seperti ke toilet, meminjam pulpen dikelas lain, atau bahkan peserta didik yang suka keluar tanpa ijin saat proses pembelajaran berlangsung.

Berkaitan dengan apa yang disampaikan di atas, maka peneliti melakukan observasi awal dengan guru matematika di SMP Negeri 6 Langsa. ${ }^{3}$ Sebagai temuan awal bahwa siswa di SMP Negeri 6 Langsa jika diberikan soal khususnya yang berkaitan dengan materi teorema phytagoras masih banyak siswa yang kebingungan dalam menjawabnya.

Hal tersebut di atas disebabkan oleh rendahnya kemampuan siswa, maka salah satu yang perlu dicermati adalah proses pelaksanaan pembelajaran. Karena pada saat proses pembelajaranlah materi pelajaran dapat dipahami oleh siswa. Rendahnya hasil belajar siswa tidak terlepas dari peran guru dalam mengelola proses pembelajaran. Menurut Slameto "Guru harus menggunakan banyak strategi pada waktu mengajar, variasi strategi mengakibatkan penyajian bahan ajaran lebih menarik perhatian siswa, mudah diterima siswa, dan kelas menjadi hidup". 4 Pada proses pembelajaran guru cenderung memindahkan pengetahuan yang dimiliki ke pikiran siswa. Selama ini siswa hanya mencatat dan mendengarkan penjelasan guru. Siswa biasanya hanya diberi rumus, contoh soal dan latihan. dan disisi lain siswa juga mengatakan bahwa masih kurang percaya diri untuk mengungkapkan jawabannya jika guru meminta tanggapannya, mereka masih kurang yakin dengan jawabannya, dan cenderung meminta jawaban teman lainnya untuk meyakinkan jawaban dari dirinya sendiri.

\footnotetext{
hlm. 18

${ }^{1}$ Erman Suherman.. Strategi Pembelajaran Kontemporer. (Bandung:JICA, 2003)

2 Moch Masykur dan Abdul Hlmim Fathani, Mathematical Intelligence: Cara Cerdas Melatih Otak dan Menanggulangi Kesulitan Belajar, (Jogjakarta:Ar-Ruzz Media, 2007), hlm.43.

3 Observasi awal dilakukan pada hari Rabu tanggal 3 Juli 2016 berdasarkan wawancara dengan guru mata pelajaran matematika di SMP Negeri 6 Langsa

${ }^{4}$ Slameto, Belajar dan Faktor-Faktor yang Mempengaruhi, (Jakarta: Rineka Cipta, 2003), hlm. 92.
} 
Kenyataan di atas disebabkan karena nilai rata-rata siswa pada hasil belajarnya masih rendah khususnya pada materi teorema phytagoras. Hail ini dapat dilihat dari nilai sebagian besar siswa masih kurang maksimal karena masih belum mencapai Kriteria Ketuntasan Minimum (KKM) yang ditetapkan di sekolah tersebut yaitu 75 (tujuh puluh lima). ${ }^{5}$ Rendahnya hasil belajar tersebut, mengakibatkan siswa harus melakukan remedial yang tentu saja tidak diharapkan oleh setiap siswa itu sendiri. Hal ini disebabkan karena nilai rata-rata siswa, selain itu ketersediaan sarana dan prasarana yang memadai, ruang kelas yang nyaman, dan tenaga pengajar yang profesional.

Percaya diri merupakan hal yang sangat penting yang seharusnya dimiliki oleh setiap siswa. Rasa percaya diri merupakan aspek afektif yang berasal dari dalam diri siswa tersebut. Dengan percaya diri siswa akan mampu meraih cita-cita yang diinginkannya. Perasaan yakin akan kemampuan yang dimiliki akan sangat mempengaruhi siswa dalam menyampaikan ide yang dimilikinya. Siswa yang memiliki rasa percaya diri akan mampu mengetahui kelebihan yang dimilikinya, karena siswa tersebut menyadari bahwa segala kelebihan yang dimiliki, kalau tidak dikembangkan, maka tidak akan ada artinya, akan tetapi kalau kelebihan yang dimilikinya mampu dikembangkan dengan optimal maka akan mendatangkan kepuasan. Sehingga jika disuruh mengerjakan soal matematika siswa dengan yakin dapat mengerjakan soal tersebut dengan kemampuan yang dimilikinya tanpa harus meminta jawaban temannya.

Dari uraian diatas faktor yang bersumber dari dalam diri siswa terutama aspek afektif atau sikap menjadi pokok penelitian ini. Aspek afektif itu adalah kepercayaan diri siswa yang kemudian dalam penelitian ini dikembangkan menjadi keyakinan diri atau self-efficacy. Bandura mendefinisikan self-efficacy sebagai judgement seseorang atas kemampuannya untuk merencanakan dan melaksanakan tindakan yang mengarah pada pencapaian tujuan tertentu. ${ }^{6}$ Bandura menggunakan istilah self-efficacy mengacu pada keyakinan (beliefs) tentang kemampuan seseorang untuk mengorganisasikan dan melaksanakan tindakan untuk pencapaian hasil. Dengan kata lain, self-efficacy adalah keyakinan penilaian diri berkenaan dengan kompetensi seseorang untuk sukses dalam tugas-tugasnya.

Melihat kondisi tersebut, maka perlu diterapkan suatu sistem pembelajaran yang efektif sehingga dapat meningkatkan kemampuan self efficacy siswa khususnya pada materi teorema phytagoras yaitu dengan penggunaan strategi pembelajaran yang dapat memacu siswa untuk lebih aktif dan menciptakan suasana pembelajaran yang menyenangkan sehingga dapat meningkatkan hasil belajar siswa.

Salah satunya dengan menggunakan Self Monitoring. Self Monitoring merupakan suatu kesadaran diri atau kemampuan orang untuk mengubah tingkahlaku menurut norma dalam situasi yang tepat. ${ }^{7}$ Materi yang akan diajarkan juga dapat dilakukan dengan strategi ini, dengan catatan siswa diberi tugas mempelajari materi yang yang akan diajarkan terlebih dahulu,

\footnotetext{
${ }^{5}$ Lia Evani, Guru Matematika SMP Negeri 6 Langsa

${ }^{6}$ Albert Bandura, Social Foundations of Thought and Action: A Social Cognitive Theory, (Englewood Cliffs, NJ: Prentice Hlml, 1986), hlm 397

${ }^{7}$ Bakhtiar Ch. Self Monitoring Sebagai Strategi Belajar Metakognitif. (Jurnal Ilmiah Guru "COPE", No. 01/Tahun VII/Februari 2003), hlm 2
} 
sehingga siswa sudah memilki bekal pengetahuan. Melalui strategi pembelajaran ini siswa diharapkan mampu menuliskan ide yang dimiliki kedalam pemecahan masalah bentuk soal cerita.

Beberapa hasil penelitian terdahulu yang berkaitan dengan penerapan Self Monitoring menyatakan bahwa terdapat peningkatan kemampuan pemecahan asalah matematika dengan menggunakan instrumen monitoring. ${ }^{8}$ Adapun kelebihan yang dimiliki oleh pembelajaran Self Monitoring ini yaitu siswa menjadi semakin kreatif dalam memecahkan kemampuan matematikanya dan bisa menciptakan siswa yang lebih aktif pada saat proses belajar.

Berdasarkan uraian di atas, maka peneliti tertarik untuk melakukan penelitian yang berjudul "Pengaruh Self Monitoring terhadap Kemampuan Self Efficacy Siswa di Kota Langsa".

\section{METODE PENELITIAN}

Dalam penelitian ini peneliti menggunakan pendekatan penelitian kuantitatif dengan metode eksperimen. Artinya penelitian yang menekankan analisisnya pada data-data numerikal (angka) yang diolah dengan metode statistika. Adapun jenis penelitian ini adalah eksperimen. Penelitian eksperimen merupakan jenis penelitian yang paling produktif karena jika penelitian tersebut dilakukan dengan baik, dapat menjawab hipotesis yang utamanya berkaitan dengan hubungan sebab-akibat. ${ }^{9}$ Desain penelitian yang digunakan dalam penelitian ini adalah One Group Pretest-Posttest Desain yaitu desain penelitian dengan menggunakan pembagian satu kelompok penelitian. ${ }^{10}$ Pada penelitian ini menggunakan kelompok penelitian eksperimen dengan menggunakan Self Monitoring.

Lokasi penelitian ini rencananya akan dilaksanakan di SMP Negeri 6 Langsa pada semester ganjil tahun ajaran 2016/2017. Penelitian ini dilaksanakan di kelas VIII pada materi teorema phytagoras dengan menggunakan strategi self monitoring, dengan waktu belajar ditetapkan 4 (empat) jam dalam 1 (satu) minggu dengan ketentuan 1 (satu) jam mata pelajaran dilaksanakan selama 40 menit. Penelitian ini direncanakan mulai bulan November 2016.

Populasi dalam penelitian ini adalah seluruh siswa kelas VIII SMP Negeri 6 Langsa yang sedang aktif belajar pada Tahun Ajaran 2016/2017 yang terdiri dari 6 (enam) kelas yang berjumlah 124 orang siswa. Sampel dalam penelitian ini diambil dengan menggunakan teknik simple random sampling yaitu teknik sampling yang dilakukan secara acak dengan menggunakan undian, ordinal, tabel bilangan random, atau komputer. ${ }^{11}$ Pengambilan sampel pada penelitian ini dengan menggunakan teknik undian yaitu dengan membuat gulungan kertas yang berisi semua populasi dari semua kelas VIII yang terdiri dari 6 kelas, kemudian diambil

\footnotetext{
${ }^{8}$ Yusuf Suryana, dkk. Penggunaan Instrumen Monitoring Diri Metakognisi Untuk Meningkatkan Kemampuan Mahasiswa Menerapkan Strategi Pemecahan Masalah Matematika. (Artikel Penelitian Ilmiah Hibah Pembinaan UPI, 2006), hlm 1-12

${ }^{9}$ Sukardi, Ph. D, Metodologi Penelitian Pendidikan, (Jakarta : Bumi Aksara, 2003), hlm. 179. 2010), hlm 110

${ }^{10}$ Sugiono. Metode Penelitian Pendidikan Pendekatan Kuantitatif, Kualitatif dan R\&D. (Bandung: Alfabeta,

${ }^{11}$ Suharsimi Arikunto, Prosedur Penelitian, (Yogyakarta : Rineka Cipta, 2010), hlm. 189.
} 
satu gulungan kertas, gulungan kertas tersebut dijadikan sebagai kelas eksperimen yaitu kelas VIII.4 dengan jumlah siswa sebanyak 21 orang siswa.

Data dalam penelitian ini akan diperoleh dengan menggunakan metode pengumpulan data berupa tes dan angket.

Instrumen penelitian adalah alat-alat yang digunakan untuk pengumpulan data. ${ }^{12}$. Instrumen penelitian merupakan alat yang digunakan untuk mengumpulkan data yang diperlukan dalam suatu penelitian. Pada penelitian ini, instrumen yang digunakan adalah tes dan non tes yang berupa angket dan lembar observasi. Data yang diperoleh kemudian dianalisis dengan menggunakan rumus statistik yang sesuai.

\section{Uji Normalitas}

Sebelum dilakukan uji hipotesis maka perlu dilakukan uji normalitas sebagai persyaratan analisis data dengan rumus Chi-kuadrat hitung ${ }^{13}$ sebagai berikut :

$$
X^{2}=\sum \frac{\left(f_{0}-f_{e}\right)^{2}}{f_{e}}
$$

Keterangan :

$X^{2} \quad$ : Kai kuadrat (chi square)

$\mathrm{f}_{\mathrm{o}} \quad$ : frekuensi observasi / pengamatan

fe $\quad$ :Frekuensi ekspektasi/ yang diharapkan

Distribusi (Tabel $\left.X^{2}\right)$ untuk $\alpha=0,05$ dan derajat kebebasan $(\mathrm{dk}=\mathrm{n}-1)$

Kriteria pengujian:

Jika $\chi_{\text {hitung }}^{2} \chi^{2}$ tabelartinya Distribusi data tidak normal

Jika $\chi^{2}{ }_{\text {hitung }}<\chi^{2}$ tabel artinya Data berdistribusi normal

\section{Pengujian Hipotesis}

Pada analisis ini dilakukan untuk menganalisis adanya pengaruh dari Self Monitoring terhadap kemampuan self efficacy matematis siswa. Analisis data ini menggunakan rumus $t_{\text {hitung }}$ yaitu sebagai berikut : ${ }^{14}$

$t_{h}=\frac{M_{D}}{S E_{M D}}$

\section{Keterangan :}

\footnotetext{
${ }^{12}$ Riduwan. Belajar Mudah Penelitian untuk Guru Karyawan dan Peneliti Muda. (Bandung: Alfabeta, 2010), hlm 110

${ }^{13}$ Riduwan. Belajar Mudah Penelitian untuk Guru-Karyawan dan Peneliti Pemula, (Jakarta: Alfabeta, 2010), hlm. 124

${ }^{14}$ Riduwan. Belajar Mudah Penelitian untuk Guru Karyawan dan Peneliti Muda. (Bandung: Alfabeta, 2010), hlm. 138
} 
$M_{D} \quad:$ Mean of Difference

$S E_{M D} \quad$ : Standar Eror Mean of Difference

\section{HASIL PENELITIAN DAN PEMBAHASAN}

Hasil analisis data diperoleh rata-rata pretes kemampuan self efficacy siswa kelas eksperimen 45,33. Selanjutnya maka kelas tersebut perlu diberikan perlakuan yang khusus, agar kemampuan self efficacy matematika siswa pada materi teorema phytagoras menjadi lebih baik, sehingga siswa memiliki keyakinan dan kepercayaan diri dalam menyelesaikan soal-soal yang diberikan yang berkaitan dengan teorema phytagoras.

Berdasarkan hasil pengujian hipotesis pada taraf signifikan $\alpha=0,05$ dengan derajat kebebasan $d k=n-2=21-2=19$ dengan kriteria Jika $t_{\text {hitung }} \geq t_{\text {tabel }}$ maka $H_{0}$ ditolak dan $H_{a}$ diterima. Berdasarkan pengujian uji $\mathrm{t}$ satu pihak diperoleh $t_{\text {hitung }} \geq t_{\text {tabel }}$ yaitu 15,60 > 2,08 sehingga $H_{0}$ ditolak dan $H_{a}$ diterima, maka dapat disimpulkan bahwa Terdapat pengaruh yang signifikan antara Self Monitoring terhadap kemampuan self efficacy siswa di kelas VIII SMP Negeri 6 Langsa pada materi teorema phytagoras.

Kelas eksperimen menggunakan pembelajaran self monitoring yang merupakan kemampuan individu dalam menampilkan dirinya terhadap orang lain dengan menggunakan petunjuk-petunjuk yang ada pada dirinya maupun petunjuk-petunjuk yang ada di sekitarnya guna mendapatkan informasi yang diperlukan untuk bertingkah laku yang sesuai dengan kondisi dan situasi yang dihadapi dalam lingkungan sosialnya. Self monitoring merupakan suatu usaha yang dilakukan individu untuk menampilkan dirinya dihadapan orang lain dengan menggunakan petunjuk-petunjuk yang ada pada dirinya atau petunjuk-petunjuk yang ada di sekitarnya. Jadi, Self Monitoring dapat membantu siswa untuk lebih memahami materi yang dipelajari khususnya pada materi teorema phytagoras. Karena pada materi teorema phytagoras membutuhkan ketelitian dan keyakinan diri dalam menyelesaikan soal-soal yang diberikan.

Selain itu, Self Monitoring juga merupakan salah satu teknik yang dapat meningkatkan kemampuan siswa dalam berkompetisi secara positif dalam pembelajaran, selain itu juga dapat mengembangkan kemampuan berpikir siswa, serta membantu siswa untuk mengingat konsep yang dipelajari secara mudah. Dengan menggunakan Self Monitoring ini, terjadi proses tanya jawab sehingga siswa berperan aktif dalam kegiatan pembelajaran.

Penelitian ini sesuai dengan penelitian yang dilakukan oleh Yusuf Suryana dalam penelitiannya yang berjudul "Penggunaan Instrumen Monitoring Diri Metakognisi Untuk Meningkatkan Kemampuan Mahasiswa Menerapkan Strategi Pemecahan Masalah Matematika" melaporkan bahwa terdapat peningkatan kemampuan pemecahan masalah matematika dengan menggunakan instrumen monitoring. ${ }^{15}$ Selain itu hasil dari penelitian Gaskill dan Murphy menunjukkan bahwa Self-Efficacy secara signifikan mempengaruhi prestasi akademik dan

\footnotetext{
${ }^{15}$ Yusuf Suryana, dkk. Penggunaan Instrumen Monitoring Diri Metakognisi Untuk Meningkatkan Kemampuan Mahasiswa Menerapkan Strategi Pemecahan Masalah Matematika. (Artikel Penelitian Ilmiah Hibah Pembinaan UPI, 2006), hlm 1-12
} 
menjadi dasar indikator yang paling kuat atas prediksi performansi dalam tugas-tugas matematika. ${ }^{16}$

Berdasarkan uraian di atas, maka dapat disimpulkan bahwa self monitoring kiranya dapat membantu siswa untuk lebih memahami pelajaran dan dapat meningkatkan kemampuan self efficacy matematika siswa sehingga mampu memberikan pengaruh yang baik pada pelajaran matematika di sekolah, khususnya bagi siswa kelas VIII SMP Negeri 6 Langsa tahun ajaran 2016/2017, serta self monitoring ini dapat meningkatkan keaktifan siswa dalam memahami isi dari materi pelajaran, Sehingga siswa belajar lebih aktif, karena memberikan kesempatan siswa mengembangkan diri, serta mampu memecahkan masalah dengan menemukan dan bekerja sama. Media pembelajaran yang digunakan yaitu Lembar Kerja Siswa (LKS). LKS tersebut digunakan untuk membantu mengukur kemampuan matematika siswa pada materi teorema phytagoras.

\section{KESIMPULAN DAN SARAN}

\section{Kesimpulan}

Berdasarkan hasil penelitian dan pembahasan pada bab IV sebelumnya, dapat disimpulkan bahwa hasil uji hipotesis data post-test kemampuan self efficacy matematika siswa diperoleh $t_{\text {hitung }}=15,60$ dan $t_{\text {tabel }}=2,08$ sehingga $t_{\text {hitung }}>t_{\text {tabel }}$. Dengan demikian dapat disimpulkan bahwa terdapat pengaruh antara Self Monitoring terhadap kemampuan self efficacy siswa di kelas VIII SMP Negeri 6 Langsa

\section{Saran}

Setelah diperoleh suatu kesimpulan dari hasil penelitian, maka peneliti memberikan saran-saran yang sekiranya bermanfaat antara lain:

1) Diharapkan bagi guru untuk dapat menerapkan, mengimplementasikan, dan memperbaharui pembelajaran matematika dengan menggunakan Self Monitoring sesuai dengan kebutuhan dan kondisi siswa agar memperoleh kemampuan self efficacy yang lebih baik serta aktivitas belajar siswa menjadi lebih aktif.

2) Diharapkan bagi peneliti yang ingin meneliti permasalahan yang sama dan dan lokasi penelitian yang berbeda agar dapat memodifikasi pembelajaran dengan menggunakan Self Monitoring dengan strategi pembelajaran lainnya sehingga tercipta suatu pembelajaran baru yang lebih baik dan dapat meningkatkan kemampuan self efficacy matematika siswa.

3) Diharapkan bagi para pembaca atau pihak yang berprofesi sebagai guru, agar penelitian ini menjadi bahan masukan dalam usaha meningkatkan mutu pendidikan di masa yang akan datang.

\section{DAFTAR PUSTAKA}

${ }^{16}$ P.J. Gaskill, P.J. dan P.K.Murphy, “Effects on a memory strategy on second graders' performance and selfefficacy" dalam Contemporary Educational Psychology, 29 (1,2004), hlm.27-49. 
Arikunto, Suharsimi. 2010. Prosedur Penelitian. Yogyakarta: Rineka Cipta

Arsyad, Azhar. 2008. Media Pembelajaran. Jakarta: Raja Grafindo Persada

Bakhtiar Ch. 2003. Self Monitoring Sebagai Strategi Belajar Metakognitif. Jurnal Ilmiah Guru "COPE", No. 01/Tahun VII/Februari

Bandura, Albert. 1986. Social Foundations of Thought and Action: A Social Cognitive Theory, Englewood Cliffs, NJ: Prentice

BSNP. 2009. Rambu-rambu Penilaian Peserta Diklat/Bimtek KTSP-Kab/Kota, Jakarta: DITPSMA

B.J. Zimmerman. 2000. Self-Efficacy: An Essential Motive to Learn. In Self efficacy beliefs. Contemporary Educational Psychology 25

Budinigsih, C. Asri. 2005. Belajar Dan Pembelajaran. Jakarta: Rineka Cipta

Hanik, Umi. 2015. http://eprints.walisongo.ac.id/355/4/Umi Hanik_Tesis_Bab2.pdf, diakses 25 Maret 2016

Jihad, Asep dan Abdul Haris. 2008. Evaluasi Pembelajaran. Yogyakarta: Multi Presindo

Kreitner, Robert \& Angelo kinicki. 1989. Organizational Behavior Second Edition. Boston: Von Hofman press

Masykur, Moch dan Abdul Hlmim Fathani. 2007. Mathematical Intelligence: Cara Cerdas Melatih Otak dan Menanggulangi Kesulitan Belajar. Jogjakarta: Ar-Ruzz Media

Ning, Lianhua. 2011. An Experimental research on the Transfer of Mathematics Skills Based On Self Monitoring Strategy. China: Nanjing Normal University, Vol 4 No 1

P.J. Gaskill, P.J. dan P.K.Murphy. 2004. "Effects on a memory strategy on second graders' performance and self-efficacy" dalam Contemporary Educational Psychology

Poerwadarmita, W.J.S. 1976. Kamus Umum Bahasa Indonesia. Jakarta: Balai Pustaka

Riduwan. 2011. Belajar Mudah Penelitian untuk Guru-Karyawan dan Peneliti Pemula, Jakarta: Alfabeta

Robert E. Slavin. 1997. Educational Psychology. Allyn Bacon

Slameto. 2003. Belajar dan Faktor-Faktor yang Mempengaruhi. Jakarta: Rineka Cipta

Sudijono, Anas. 1995. Pengantar Evaluasi Pendidikan, Jakarta: Raja Grafindo Persada

Sugiono. 2010. Metode Penelitian Pendidikan Pendekatan Kuantitatif, Kualitatif dan R\&D. Bandung: Alfabeta

Suherman. 2001. Strategi Pembelajaran Matematika Kontemporer. Bandung: JICA

Suherman, Erman. 2003. Strategi Pembelajaran Kontemporer. Bandung: JICA

Sukardi. 2003. Metodologi Penelitian Pendidikan, Jakarta: Bumi Aksara

Supardi, dkk. 2009. Pengantar Statistik Pendidikan. Jakarta: Diadit Media

Suryana, Yusuf dkk. 2006. Penggunaan Instrumen Monitoring Diri Metakognisi Untuk Meningkatkan Kemampuan Mahasiswa Menerapkan Strategi Pemecahan Masalah Matematika. Artikel Penelitian Ilmiah Hibah Pembinaan UPI

Steven, Penrod. 1983. Social Psychology. Prentice Hlml Inc Englewood Cliff NJ 
Widiyanto, E. 2006. Hubungan Antara Self Efficacy dengan Efektifitas komunikasi pada Receptionist Hotel. Skripsi: Fakultas Psikolagi Universitas Muhammadiyah Malang Yusuf, Syamsul dan Juntika Nurihsan. 2008. Teori Kepribadian. Bandung : Remaja Rosda Karya 